\title{
State of Annual Paid Leave-Doctors' Working Conditions
}

\author{
GO Igusa, Katushi Mizuno, Eiji Takeda, Shunici Yasuda, and \\ Masahiko Ichikawa
}

Received: 18 January 2019

Accepted: 24 March 2019

Published: 31 March 2019

Publishing services provided by Knowledge E

(c) GO Igusa et al. This article is distributed under the terms of the Creative Commons

Attribution License, which permits unrestricted use and redistribution provided that the original author and source are credited.

Selection and Peer-review under the responsibility of the First ELEHIC Conference Committee.

\section{Survey Objectives}

While it has been a long time since a term "black company", in which they exploit their employees under execrable working environment, became generalized in Japan, another term "black hospital", in which they impose excessive working hours on hospitalbased doctors, has been recently introduced.

This "black hospital" nowadays is a serious issue in Japan. In the field of Japanese medical services, there are hospital-based doctors who have been forced to work under execrable working environment where they can hardly take any days off and are at the risk of karoshi, death from overwork.

The problem associated with demands and supplies, such as uneven distribution of doctors, has also been actualized; it is an urgent issue to comprehensively resolve this situation from the aspects of labor policies such as by improving working conditions of doctors or by rebuilding demand-supply coordination system, in order to satisfy demand for doctors' works and to establish and maintain safe and secure medical service systems in the future. Needless to say, it is especially important for doctors to take annual paid leave of "holidays" where they can relieve cumulative fatigue and rest mentally and physically whenever they need. Medical services involve various social factors in a complex manner. A single and short-sighted measure will induce another problem. Therefore, from a long-term perspective, it is necessary to create a vision while looking into the future of medical services in Japan and to resolve the labor issues of doctors on the basis of the long-term vision of the future.

In this article, significance of actual situation of "annual paid holiday", which is a crucial element for working condition of doctors, is discussed through quantitative analysis of questionnaire survey conducted in "hospital-based doctors".

\section{S OPEN ACCESS}




\section{Data to Be Used}

Individual data obtained in the "survey on annual paid leave of hospital-based doctors" consigned to and conducted by Rakuten Research, Inc. in 2015 were included in this survey (This survey was conducted using internet in doctors working at hospitals all over Japan (excluding directors of hospitals and clinics). The samples were randomly extracted. The number of distributions had been determined so that 800-1000 samples would be collected.) Igusa (2015) presented the results of simple aggregation of the individual data. In order to generalize these individual data, t-test and analysis of variance (ANOVA) were performed on differences in the number of annual leave days for each item. Then, following results were obtained (Table 1). 
TABLE 1: Simple totaling results of the number of annual leave days taken by doctors.

\begin{tabular}{|c|c|c|c|c|c|}
\hline & & n value & $\%$ & $\begin{array}{l}\text { Mean vilue of the } \\
\text { number of annual } \\
\text { leave dage taken }\end{array}$ & \begin{tabular}{|l} 
T value, F \\
value
\end{tabular} \\
\hline & tockal & 800 & 1000 & 5.8 & \\
\hline Gender & $\begin{array}{l}\text { Male } \\
\text { Fennale } \\
\end{array}$ & $\begin{array}{r}709 \\
91 \\
\end{array}$ & $\begin{array}{l}88.6 \\
11.4 \\
\end{array}$ & $\begin{array}{l}5.8 \\
5.9 \\
\end{array}$ & 0.151 \\
\hline$A=0$ & 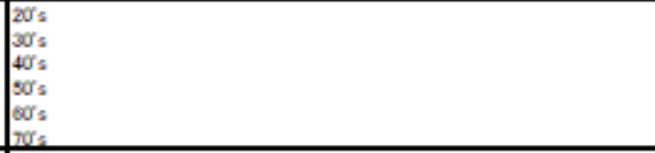 & $\begin{array}{r}13 \\
138 \\
265 \\
317 \\
68 \\
1\end{array}$ & $\begin{array}{r}1.6 \\
17.3 \\
33,1 \\
39.8 \\
8.3 \\
0.1 \\
\end{array}$ & $\begin{array}{l}5.0 \\
5.1 \\
5.5 \\
6.4 \\
6.0 \\
5.0 \\
\end{array}$ & 1,416 \\
\hline Marvied atatus & $\begin{array}{l}\text { Unmarried } \\
\text { Married } \\
\text { Dhoroes or wiblowed }\end{array}$ & $\begin{array}{r}103 \\
668 \\
29 \\
\end{array}$ & $\begin{array}{r}12.9 \\
83.5 \\
3.5 \\
\end{array}$ & $\begin{array}{l}4.7 \\
6.0 \\
6.6 \\
\end{array}$ & 2.283 \\
\hline Children & $\begin{array}{l}\text { How } \\
\text { Donok have }\end{array}$ & $\begin{array}{l}608 \\
192 \\
\end{array}$ & $\begin{array}{r}76,0 \\
24.0 \\
\end{array}$ & $\begin{array}{r}6.1 \\
5.0 \\
\end{array}$ & $2.528 *$ \\
\hline Gradueted uniwersity & $\begin{array}{l}\text { High ranke d putic uniwersky } \\
\text { Low ranled patlic uniweraty } \\
\text { High ranled pivate uniwersity } \\
\text { Low ranled pivate uniwersity }\end{array}$ & $\begin{array}{r}316 \\
277 \\
119 \\
88 \\
\end{array}$ & \begin{tabular}{r|}
39.5 \\
34.5 \\
14.9 \\
11.0 \\
\end{tabular} & $\begin{array}{l}5.8 \\
5.8 \\
5.7 \\
6.1 \\
\end{array}$ & 0.098 \\
\hline $\begin{array}{c}\text { Do you belon } \mathrm{z} \text { to a medicd } \\
\text { office? }\end{array}$ & $\begin{array}{l}Y_{65} \\
\mathrm{H}_{0}\end{array}$ & $\begin{array}{l}446 \\
354 \\
\end{array}$ & $\begin{array}{l}55,8 \\
44,3 \\
\end{array}$ & $\begin{array}{l}5.6 \\
6.1 \\
\end{array}$ & 0.180 \\
\hline Last year's annual income (al) & $\begin{array}{l}\text { between } 1-3 \text { million yen } \\
\text { betweon } 3-5 \text { million yen } \\
\text { between } 5-7 \text { million yen } \\
\text { between } 7-10 \text { million yen } \\
\text { betwesn } 10-15 \text { million yen } \\
\text { between } 15-20 \text { mallion yen } \\
20 \text { million yen or maore }\end{array}$ & $\begin{array}{r}6 \\
14 \\
23 \\
59 \\
212 \\
282 \\
204 \\
\end{array}$ & \begin{tabular}{r|}
0.8 \\
1.8 \\
2.9 \\
7.4 \\
28.5 \\
35.3 \\
25.5 \\
\end{tabular} & \begin{tabular}{l|}
7.0 \\
5.1 \\
5.4 \\
4.9 \\
5.4 \\
5.9 \\
6.5 \\
\end{tabular} & 0.970 \\
\hline Working hours per wook (all) & $\begin{array}{l}\text { less than } 20 \mathrm{hrs} \\
\text { between } 20-40 \mathrm{hrs} \\
\text { between } 40-50 \mathrm{hrs} \\
\text { between } 50-60 \mathrm{hrs} \\
\text { between } 60-70 \mathrm{hrs} \\
\text { between } 70-80 \mathrm{hrs} \\
00 \text { hrs or more }\end{array}$ & $\begin{array}{r}4 \\
79 \\
292 \\
197 \\
128 \\
43 \\
57 \\
\end{array}$ & \begin{tabular}{r|}
0.5 \\
9.9 \\
35.5 \\
24.5 \\
16.0 \\
5.4 \\
7.1 \\
\end{tabular} & \begin{tabular}{l|}
8.0 \\
6.3 \\
6.4 \\
5.4 \\
5.9 \\
5.3 \\
3.6 \\
\end{tabular} & $3,670 \cdots$ \\
\hline $\begin{array}{l}\text { Puniter of prescrites h holidays } \\
\text { per woek }\end{array}$ & 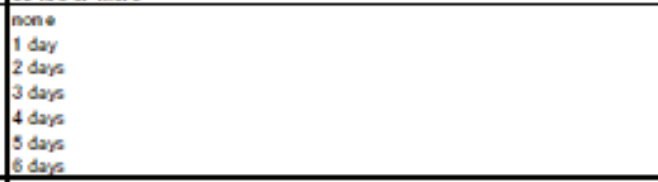 & $\begin{array}{r}34 \\
199 \\
524 \\
27 \\
2 \\
13 \\
1 \\
\end{array}$ & \begin{tabular}{r|}
4.3 \\
24.9 \\
65.5 \\
3.4 \\
0.3 \\
1.5 \\
0.1 \\
\end{tabular} & \begin{tabular}{l|}
4.1 \\
5.3 \\
6.1 \\
6.2 \\
2.0 \\
5.0 \\
0.0 \\
\end{tabular} & 1,416 \\
\hline $\begin{array}{c}\text { Paniber of daty facilities in the } \\
\text { bast month }\end{array}$ & $\begin{array}{l}1 \text { place } \\
2 \text { places } \\
3 \text { places } \\
4 \text { places } \\
5 \text { places } \\
6 \text { places } \\
7 \text { places } \\
8 \text { places } \\
9 \text { places } \\
10 \text { places or more }\end{array}$ & $\begin{array}{r}449 \\
169 \\
95 \\
45 \\
21 \\
7 \\
3 \\
3 \\
0 \\
5\end{array}$ & \begin{tabular}{r|}
56.1 \\
21.1 \\
12.3 \\
5.6 \\
2.6 \\
0.9 \\
0.4 \\
0.4 \\
0.0 \\
0.6 \\
\end{tabular} & \begin{tabular}{l|}
5.8 \\
6.7 \\
5.7 \\
4.5 \\
3.0 \\
6.9 \\
4.0 \\
3.3 \\
- \\
2.4 \\
\end{tabular} & 1,650 \\
\hline $\begin{array}{c}\text { Manaze ment form (im an } \\
\text { wortiplace) }\end{array}$ & 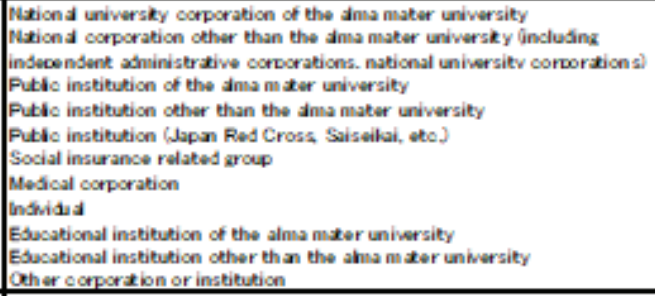 & $\begin{array}{r}30 \\
43 \\
22 \\
98 \\
119 \\
15 \\
357 \\
31 \\
19 \\
25 \\
41 \\
\end{array}$ & \begin{tabular}{r|r|r}
3.8 \\
5.4 \\
2.8 \\
12.3 \\
14.9 \\
1.9 \\
44.8 \\
3.9 \\
2.4 \\
3.1 \\
5.1 \\
\end{tabular} & \begin{tabular}{l|}
3.3 \\
6,7 \\
5,9 \\
6.4 \\
5,6 \\
6.5 \\
5,9 \\
3.7 \\
5,1 \\
5,9 \\
6.8 \\
\end{tabular} & 1,349 \\
\hline $\begin{array}{c}\text { Type of hospkal (min } \\
\text { wortiplixe) }\end{array}$ & $\begin{array}{l}\text { Acute care hospital and ent eriancy hospital } \\
\text { Acute care hospital } \\
\text { Energency hospitd } \\
\text { Wone of the above. }\end{array}$ & $\begin{array}{r}364 \\
111 \\
34 \\
271 \\
\end{array}$ & $\begin{array}{r}43.0 \\
13.9 \\
4.3 \\
33.9 \\
\end{array}$ & \begin{tabular}{l|}
5.6 \\
5.6 \\
4.6 \\
6.4 \\
\end{tabular} & 1,343 \\
\hline $\begin{array}{c}\text { Locsion of the ho pital (main } \\
\text { workplace) }\end{array}$ & $\begin{array}{l}\text { Loo ted in an ordn ane e-desian ted city, or the } 23 \text { warts of Tolyo } \\
\text { Loc ted in a depopulted rural ares } \\
\text { Wone of the above }\end{array}$ & $\begin{array}{l}334 \\
330 \\
135 \\
\end{array}$ & $\begin{array}{r}41,8 \\
41,3 \\
17,0 \\
\end{array}$ & $\begin{array}{l}5.8 \\
5.8 \\
5.9 \\
\end{array}$ & 0,009 \\
\hline $\begin{array}{c}\text { Numiter of sickbed (main } \\
\text { workplixes) }\end{array}$ & $\begin{array}{l}49 \text { beds or less } \\
30-99 \text { beds } \\
100-299 \text { beds } \\
300-499 \text { beds } \\
500-999 \text { beds } \\
1000 \text { beds or more }\end{array}$ & $\begin{array}{r}135 \\
56 \\
242 \\
168 \\
158 \\
41\end{array}$ & $\begin{array}{r}16.9 \\
7.0 \\
30.3 \\
21.0 \\
19.8 \\
5.1\end{array}$ & $\begin{array}{l}6.6 \\
5.3 \\
5.4 \\
5.8 \\
6.0 \\
5.4 \\
\end{array}$ & 0,788 \\
\hline
\end{tabular}




\begin{tabular}{|c|c|c|c|c|c|}
\hline Department (main workipices) & 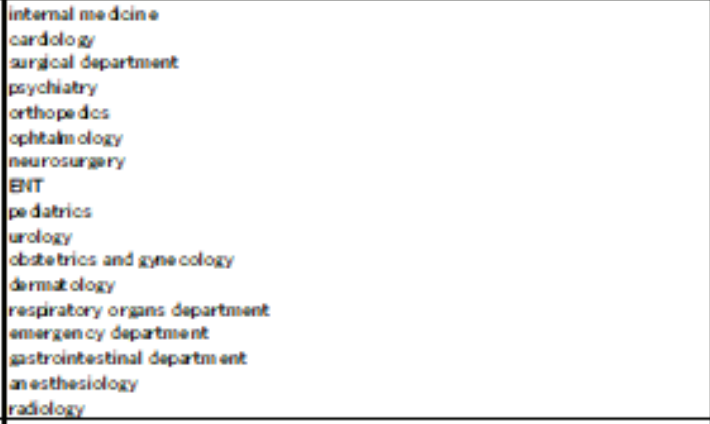 & \begin{tabular}{r|}
243 \\
35 \\
34 \\
49 \\
67 \\
25 \\
26 \\
20 \\
37 \\
22 \\
31 \\
18 \\
10 \\
15 \\
25 \\
50 \\
33 \\
\end{tabular} & $\begin{array}{r}30.4 \\
4.4 \\
11.8 \\
6.1 \\
8.4 \\
3.1 \\
3.3 \\
2.5 \\
4.5 \\
2.8 \\
3.9 \\
2.3 \\
1.3 \\
1.9 \\
3.1 \\
6.3 \\
4,1 \\
\end{array}$ & $\begin{array}{l}6.3 \\
6.6 \\
4,7 \\
4.9 \\
6.4 \\
7.0 \\
4.1 \\
5.7 \\
7.1 \\
5.5 \\
3.0 \\
7.3 \\
7.7 \\
7.3 \\
4.3 \\
5.8 \\
6.1 \\
\end{array}$ & $2.673 \cdots$ \\
\hline $\begin{array}{c}\text { Puanter of jeass experience } \alpha \\
\text { a doctor }\end{array}$ & $\begin{array}{l}\text { less than } 1 \text { year } \\
\text { betweon } 1-3 \text { years } \\
\text { betweon } 3-5 \text { years } \\
\text { betweon } 5-10 \text { years } \\
\text { betweon } 10-15 \text { years } \\
15 \text { years ore more }\end{array}$ & \begin{tabular}{r|}
7 \\
11 \\
18 \\
58 \\
108 \\
602 \\
\end{tabular} & \begin{tabular}{r|}
0.9 \\
1.4 \\
2.3 \\
7.0 \\
13.3 \\
75.3 \\
\end{tabular} & $\begin{array}{l}0.9 \\
6.5 \\
5.4 \\
4.8 \\
5.5 \\
6.0\end{array}$ & 1,580 \\
\hline $\begin{array}{l}\text { Phantber of years of service } \\
\text { (main worlplace) }\end{array}$ & $\begin{array}{l}\text { less than } 1 \text { your } \\
\text { betweon } 1-3 \text { yours } \\
\text { betweon } 3-5 \text { years } \\
\text { between } 5-10 \text { years } \\
\text { betweon } 10-15 \text { years } \\
15 \text { yexs ore more }\end{array}$ & \begin{tabular}{r|}
73 \\
140 \\
100 \\
214 \\
114 \\
159 \\
\end{tabular} & \begin{tabular}{r|}
9.1 \\
17.5 \\
12.5 \\
26.8 \\
14.3 \\
19.9
\end{tabular} & $\begin{array}{l}4.7 \\
4.7 \\
5.9 \\
6.2 \\
6.4 \\
6.5 \\
\end{array}$ & $2.445 *$ \\
\hline Podtion (main workplace) & 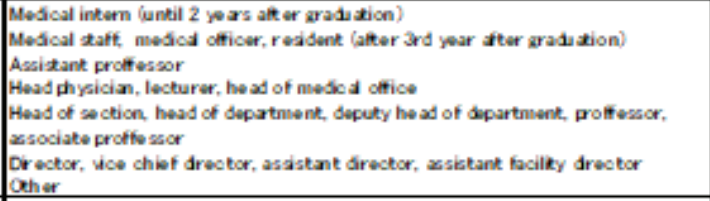 & \begin{tabular}{r|r|r}
15 & \\
34 & \\
159 & \\
257 & \\
154 & \\
35 & &
\end{tabular} & \begin{tabular}{r|r|}
1.0 \\
19.0 \\
4.3 \\
19.9 \\
32.1 \\
19.3 \\
4.5 \\
\end{tabular} & $\begin{array}{l}1.9 \\
5.5 \\
5.5 \\
5.7 \\
6.3 \\
5.6 \\
6.4\end{array}$ & $4.261 *$ \\
\hline $\begin{array}{l}\text { Paniber of dysa of annual leswe } \\
\text { talen (min workpiace) }\end{array}$ & 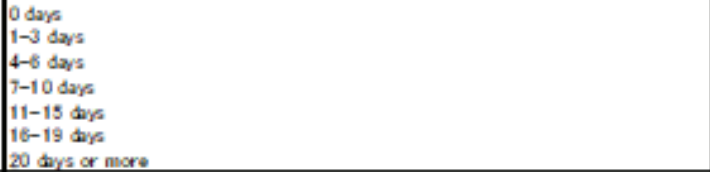 & $\begin{array}{r}196 \\
130 \\
180 \\
190 \\
57 \\
8 \\
39\end{array}$ & $\begin{array}{r}24.5 \\
16.3 \\
22.5 \\
23.5 \\
7.1 \\
1.0 \\
4.9\end{array}$ & $\begin{array}{l}- \\
- \\
- \\
- \\
-\end{array}$ & \\
\hline $\begin{array}{l}\text { Peaniber of anual leave days } \\
\text { given (main workplace) }\end{array}$ & $\begin{array}{l}0 \text { daya } \\
1-5 \text { days } \\
6-10 \text { daye } \\
11-15 \text { dya } \\
16-20 \text { dye } \\
21 \text { dys or more }\end{array}$ & \begin{tabular}{r|}
301 \\
65 \\
110 \\
44 \\
223 \\
57 \\
\end{tabular} & \begin{tabular}{r|}
37.6 \\
8.1 \\
13.8 \\
5.5 \\
27.9 \\
7.1 \\
\end{tabular} & $\begin{array}{l}3.9 \\
4.9 \\
5.4 \\
7.7 \\
8.1 \\
7.8 \\
\end{array}$ & $16,461 \cdots$ \\
\hline $\begin{array}{l}\text { Method of taking annual peid } \\
\text { loave (main workplace) }\end{array}$ & 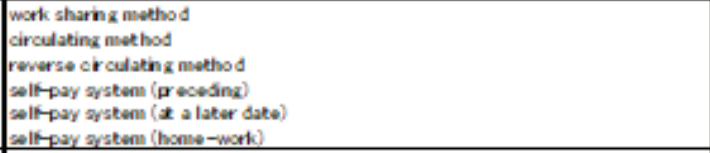 & \begin{tabular}{r|}
439 \\
23 \\
57 \\
178 \\
64 \\
39 \\
\end{tabular} & $\begin{array}{r}54.9 \\
2.9 \\
7.1 \\
22.3 \\
8.0 \\
4.9 \\
\end{array}$ & \begin{tabular}{l|}
6.0 \\
5.9 \\
6.0 \\
6.2 \\
5.5 \\
2.3 \\
\end{tabular} & $3.169 *$ \\
\hline $\begin{array}{c}\text { Folsod to the medcal service } \\
\text { M.A.) (nn in workpisce) }\end{array}$ & 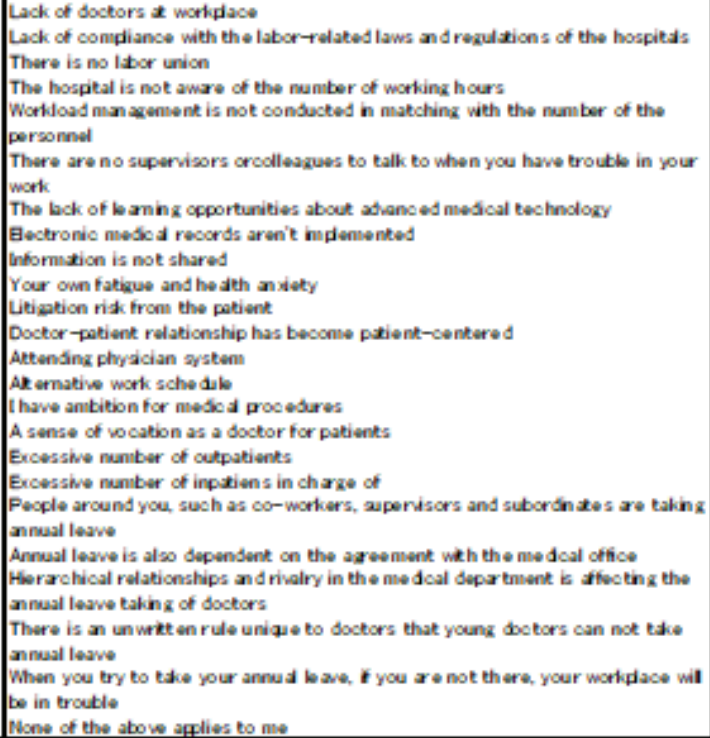 & \begin{tabular}{r|r}
430 \\
150 \\
237 \\
94 \\
138 \\
82 \\
105 \\
168 \\
79 \\
196 \\
149 \\
69 \\
250 \\
37 \\
144 \\
202 \\
112 \\
62 \\
59 \\
42 \\
24 \\
32 \\
158 \\
32
\end{tabular} & $\begin{array}{r}54.1 \\
18.8 \\
29.5 \\
11.8 \\
17.3 \\
10.3 \\
13.1 \\
21.0 \\
9.9 \\
24.5 \\
18.5 \\
8.5 \\
35.3 \\
4.5 \\
18.0 \\
25.3 \\
14.0 \\
7.8 \\
7.4 \\
5.3 \\
3.0 \\
4.0 \\
19.8 \\
10.3\end{array}$ & $\begin{array}{l}5.4 \\
5.3 \\
5.7 \\
5.6 \\
5.7 \\
5.1 \\
5.2 \\
5.8 \\
5.7 \\
5.3 \\
5.8 \\
5.1 \\
5.6 \\
8.6 \\
5.4 \\
5.6 \\
5.4 \\
6.9 \\
6.3 \\
5.1 \\
3.4 \\
2.6 \\
5.0 \\
6.5\end{array}$ & 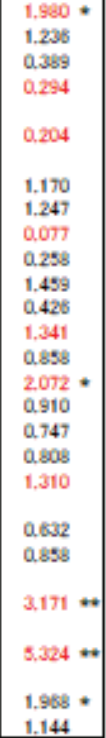 \\
\hline
\end{tabular}




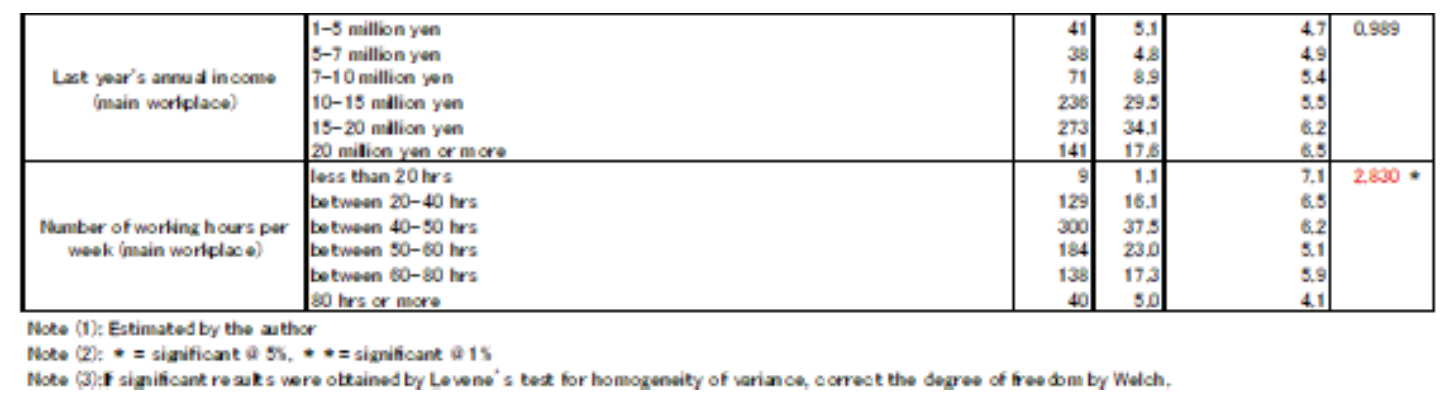

1. The number of annual leave days varied according to presence or absence of children, age group, hospital department in charge, years of service, position at work, the system of taking annual paid leave, number of doctors in the workplace, work system, features of medical society, and working hours.

2. The number of annual leave days is especially small in particular hospital departments (especially surgical specialties). Moreover, as indicated by Igusa (2013) through an interview survey, the number of annual leave days was significantly smaller in doctors who had been feeling an unwritten law of medical society (doctors who are at lower positions, young doctors, and those who had been feeling a hierarchical relationship among medical schools, etc.)

3. Differences were observed in items associated with substitution when doctors were taking annual paid leave.

These facts were revealed from the results of basic data aggregation. However, in order to reveal complicated context of situations where they can actually take annual paid leave, effects of individual factors will need to be observed by setting certain other conditions, followed by quantitative assessments through empirical analyses on the effects of individual factors.

\section{Variables, Methods and Results}

Then what sort of items will affect the doctor's taking annual paid leave? This is verified below by performing censored model regression analysis using the number of annual leave days as dependent variable (The number of annual leave days was " 0 " in 196 cases (24.5\% of 799 effective samples). Therefore, in selection of an analysis method, a censored model which is appropriate for distributions where dependent variables have been discontinued, was used.), (Not all variables in the second paragraph were included as there was a problem with multicollinearity.). 
In order to observe the effects of working environment (in the broad sense) on taking annual paid leave, the following factors were included as dependent variables in addition to the variables associated with how they work: medical office they belong to, hospital department in charge, and hospital attributes. Control variables include variables associated with basic attributes. Two formulas were estimated; one included subjective responses in multiple answers, and another one not. The Table 2 shows descriptive statistics of variables used in analyses, and the Table 3 presents the results.

According to the results, for both of the estimated formulas, significant differences were observed in doctors working in private hospitals, working in emergency hospitals, being in charge of obstetrics and gynecology department and dermatology department, the number of annual leave days, self-pay system (at a later date), self-pay system (homework) (The person who took annual paid leave performs his task by himself without letting others do this. Refer to Igusa (2014) for methods of taking annual paid leave.), and alternative work schedule. In addition, from the estimated formula- 2 , it was revealed that remarkable difference was observed in the number of annual leave days according to the working environments with excessive number of inpatients in charge of, unwritten rules unique to doctors, and feelings that if they are not there, their workplace will be in trouble.

TABLE 2: Descriptive statistics.

\begin{tabular}{|c|c|c|c|c|}
\hline Variable name & Average & $\begin{array}{l}\text { Standard } \\
\text { deviation }\end{array}$ & $\begin{array}{l}\text { Maximum } \\
\text { value }\end{array}$ & $\begin{array}{l}\text { Minimum } \\
\text { value }\end{array}$ \\
\hline$\overline{A g e}$ & 48.14 & 8.94 & 76 & 24 \\
\hline Married* & 083 & 0.37 & 1 & 0 \\
\hline Divorced $\alpha$ widowed* & 004 & 0.19 & 1 & 0 \\
\hline Female* & 0.11 & 0.32 & 1 & 0 \\
\hline Have Children* & 0.76 & 0.43 & 1 & 0 \\
\hline Do you belong to a medical of fice? Yeg* & 0.56 & 0.50 & 1 & 0 \\
\hline Last year's annusl income (main workplace) & 141781 & 576.24 & 4000 & 10 \\
\hline Number of working hours per week (msin workplace) & 48.16 & 14.26 & 110 & 2 \\
\hline Number of prescribed holidays per week & 1.76 & 0.75 & 6 & 0 \\
\hline Number of duty faciilities in the last month & 188 & 1.38 & 10 & 1 \\
\hline National university corporation of the alma mater university*: & 004 & 0.19 & 1 & 0 \\
\hline $\begin{array}{l}\text { National corporation other than the alma mater uriver sity (including independent } \\
\text { administrative corporations, national uriver sity corparstions)* }\end{array}$ & 005 & 0.23 & 1 & 0 \\
\hline Public institution of the alma mater university* & 0.03 & 0.16 & 1 & 0 \\
\hline Public institution other than the alma mater university* & 0.12 & 0.33 & 1 & 0 \\
\hline Public institution (Japan Red Cross, Saiseikai, etc.)* & 0.15 & 0.36 & 1 & 0 \\
\hline Social insurance related groupk & 0.02 & 0.14 & 1 & 0 \\
\hline Ind vidusl* & 0.04 & 0.19 & 1 & 0 \\
\hline Educational institution of the alma mater university* & 0.02 & 0.15 & 1 & 0 \\
\hline Educational institution other than the alma mater university* & 0.03 & 0.17 & 1 & 0 \\
\hline Other corparstion or institution* & 0.05 & 0.22 & 1 & 0 \\
\hline Acute care hospital and emergency hospital* & 0.48 & 0.50 & 1 & 0 \\
\hline Acute care hospital* & 0.14 & 0.34 & 1 & 0 \\
\hline Emergency hospital* & 0.04 & 0.20 & 1 & 0 \\
\hline Located in an ordinance-designated city, or the 23 wards of Tokyo* & 0.42 & 0.49 & 1 & 0 \\
\hline Located in a depopulated rural areak & 0.41 & 0.40 & 1 & 0 \\
\hline
\end{tabular}


50-99 beds

100-299 beds*

300-499 beds*

500-999 beds*

1000 beds or more*

cerdologye:

surical department*

psychiatry*

orthopedics*

ophtalmology*

neurosuryer

ENT*

pediatrics*

urologye:

obetetrics and gynecology*

dermatology*

respiratory orgens depstment*

emergency departmente:

gastraintestinal department

anesthesiologye:

radiology*

Paid holidsys used

Number of annual leave days given (main workplace)

circulating method*

reverse circulating method*

self-pay system (preceding)

self-pay system (at a later date)*

self-pay system (home-work)*

Lack of doctors at workplace*

Lack of compliance with the labor-related laws and regulations of the hospital g*

There is no lsbor union*

The hospital is not aware of the number of working hours*

Workload management is not conducted in matching with the number of the personnel*

There are no supervisors orcollesgues to talk to when you have trouble in your work*

The lack of leaming opporturities about advanced medical techndogy*

Eectroric medcal records aren't implemented*

Information is not shared*

Your own fatigue and heal th ansiety*

Litigation risk from the patient*

Doctor-pstiert relationship has become pstient-centered*

Attending physician system*

Altemative work schedulex

I have ambition for medcal procedures*

A sense of vocation as a doctor for pstients*

Excessive number of cutpatients*

Excessive number of incatiens in charge of*

People around you, such as co-workers, supervisors and subordinstes are taking annual legver.

Annual leave is also dependent on the agreemert with the medcal office*

Hierarchical relationships and rivalry in the medical department is affecting the annual legve taking of doctors*

There is an umwitten rule unique to doctors that young doctors can not take annual

legver.

When you try to take your annugl legve, if you are not there, your worklace will be in

trouble:

Note (1): The sample size is 799 .

Note (2): * represents dummy variable.

The results of analyses revealed followings and indicated measures to be taken. 
TABLE 3: Influence of the variable on use of paid holidays (censored model).

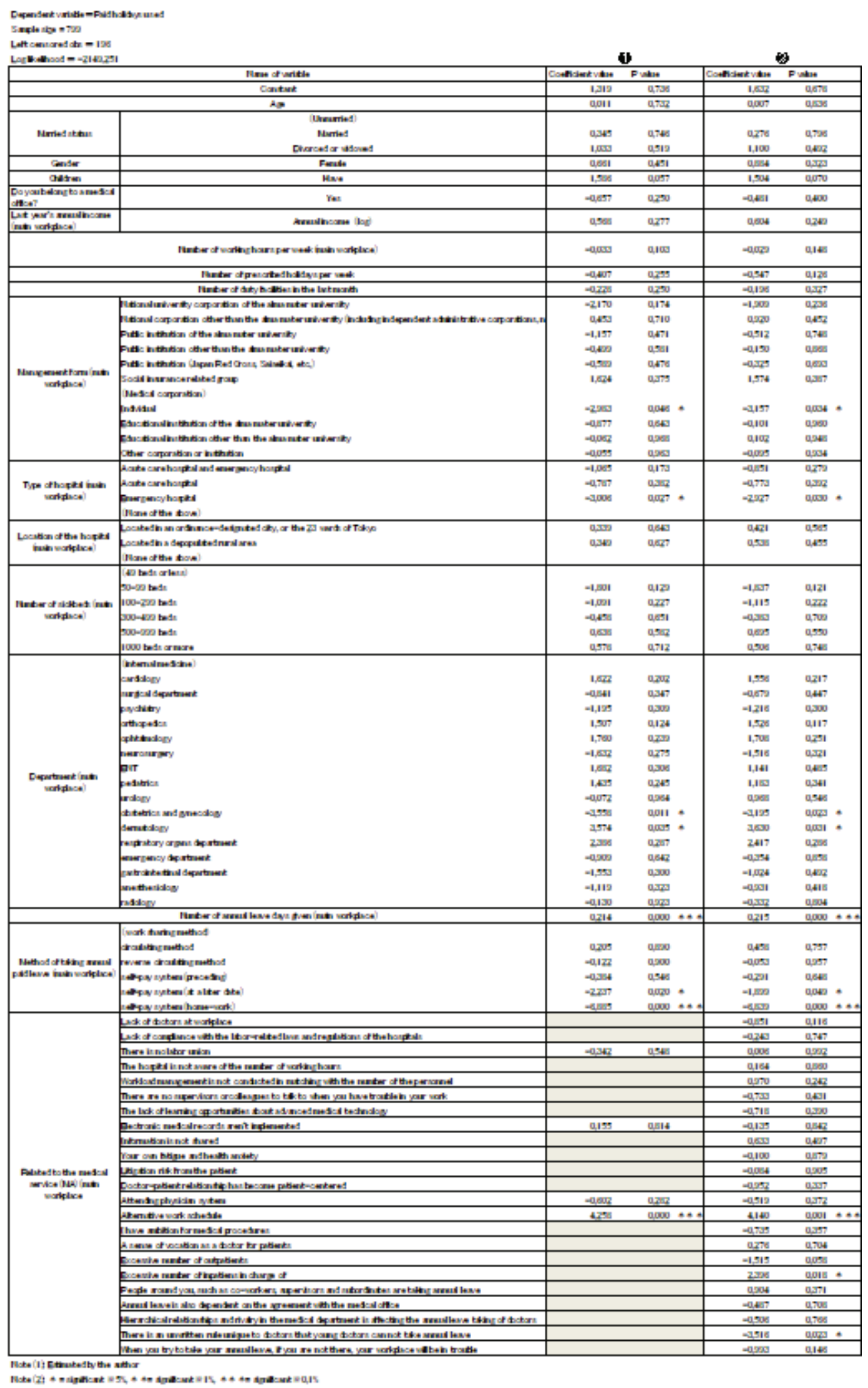

First of all, the fact that doctors are in charge of surgical department does not necessarily prevent them from taking annual paid leave in a direct manner (Significant results 
were not observed in surgical doctors when conditions were controlled with variables associated with alternative work schedule, methods of annual paid leave, and the number of doctors.). Although it has been recently pointed out that doctors especially in surgical fields are suffering from overwork such as no holidays due to their high specialty, the problem is not their skills but rather an absolute lack of number of doctors. The results of analysis indicated that it is crucial to increase the number of doctors significantly and establish a shift system in order to improve the conditions for taking annual paid leave. Some hospitals are using a system where a team of 3 doctors including a resident, fellow and consultant is involved in treatment of 1 patient so that they can take days-off whenever they need without any concerns. However, this system cannot be introduced if the number of doctors is too small. Therefore, it needs to be considered at the same time to increase the number of doctors and to establish the shift system.

Secondly, negative effects were observed on taking annual paid leave in cases where they work at private hospitals or clinics. If they work in hospitals, etc. and perform their tasks following directions provided by these hospitals, the corresponding doctors are considered as labors under the labor law and protected by this law. However, they are actually hardly aware of this fact (Mizushima, 2010). It appears that the smaller the hospital, the more obvious this tendency becomes as in a case of a business corporation. It is required for the national government or the third party organizations to organize and assess the labor law issues associated with hospital-based doctors and to improve the level of knowledge regarding the law of annual paid leave mainly in private hospitals and clinics.

Thirdly, the model 2 indicated that negative effects were imposed on annual paid leave in cases where there was an unwritten rule unique to doctors that young doctors could not take annual leave. It may reflect the fact that expectations on young doctors are higher than ever under circumstances with a lack of doctors or uneven distribution of doctors. However, this should not be overlooked considering recent karoshi (death from overwork) of young doctors. In the field of medical services, there are some local rules unique to specialist groups under a strict hierarchy. However, not only the hospitals but also the medical offices may need to reconsider that these young doctors are also labors protected under the labor law.

Many researchers have pointed out that in general there is the tendency of "neglect or ignorance of the labor law at workplaces" are becoming more prominent in the field of medical services. Therefore, further discussion will be needed in the future on issues regarding taking annual paid leave in Japan. 


\section{References}

[1] Igusa, G. (2013) Factors affecting young doctors to not take annual paid leave. Journal of Labor Sociology, 14, 105-132.

[2] Igusa, G. (2014) Economic analysis of six methods of taking paid vacation - Labor and Social Science results and application. The Annual Report of Economic Science, 52, 1-7.

[3] Igusa, G. (2015) Survey of annual paid leave acquisition of hospital physicians in Japan (2015). International Journal of Social Science Studies, 3(6), 202-210.

[4] Mizushima, I. (2010) Labor law issues on hospital physicians. Japanese Journal of Labour Studies, 52(1), 42-52. 